\title{
A Systematic Review of Research on Teaching English Language Skills for Saudi EFL Students
}

\author{
Hamad H. Alsowat* \\ College of Education, Taif University, P.O.Box:888, Taif, Saudi Arabia
}

Corresponding Author: Hamad H. Alsowat, E-mail: hhhs_2005@hotmail.com

\section{ARTICLE INFO}

Article history

Received: June 11, 2017

Accepted: September 10, 2017

Published: October 31, 2017

Volume: 8 Issue: 5

Advance access: October 2017

Conflicts of interest: Non

Funding: None

Key words:

English Language Teaching,

ELT,

Language Skills,

Saudi Arabia,

Systematic Review

\begin{abstract}
This systematic review study sought to examine the teaching of English language skills in Saudi Arabia by systematically analyzing the previous studies on language skills which were published within the past ten years and identify the research areas to be bridged in the future. The study employed the systematic review approach. The search strategy yielded 221 studies for inclusion in the systematic keyword map, and 95 studies for in-depth review. The findings of this systematic review revealed that students sampling presented (80.09\%) in those studies, and female students participated in only $(24.43 \%)$ of those studies. In addition, $(73.30 \%)$ of the conducted studies were at the university level indicating a limit interest of the school-level research. In addition, $(68.52 \%)$ of those studies focused on writings kills, reading skills and achievement indicating the necessity to give more attention to speaking, listening, pronunciation, vocabulary and grammar research at all education sectors in the future. The in-depth review also indicated an obvious focus on reading and writing skills and most the studies were undertaken at the university level. The findings were discussed and a number of language skills research gaps were pointed out
\end{abstract}

\section{INTRODUCTION}

In recent years, English language is considered the dominant language worldwide. This importance comes as a result of its role in education, industry, commerce, media, business, technology, trade etc. "For better or worse, by choice or force, English has 'traveled' to many parts of the world and has been used to serve various purposes (Sharifian, 2009:1). English language teaching, hereinafter (ELT), "obscures the complexity of a field which incorporates teaching and learning English as second, additional or foreign language or as an international lingua franca; for specific, academic or more general purposes: in different countries and contexts; and at different levels" (Hall: 2016:1).ELT affirms itself as a specialty of particular academic interest with professorships, research grants, journals, conferences and so on (Littlejohn, 2013).Therefore, teachers and ELT professionals need to be aware of the contemporary status of the language and of the issues for both learners, institutions and policymakers to tailor their professional practice to the circumstances of their students and to the contexts in which those students will be using the language (Seargeant, 2016). Research on teaching English language skills in Saudi Arabia witnessed rapid development within the past decade. This development has generated hundreds of research papers that dealt with language skills, but those research papers have not been an- alyzed before to explore their contribution to English language teaching in Saudi Arabia. So, this study attempts to bridge this research gap since no similar studies have been conducted in the Saudi context.

\section{Education System in Saudi Arabia}

The Kingdom of Saudi Arabia was established in 1932. It is the largest country in producing oil in the Middle East. It witnesses a rapid growth in all fields. Education has been given a special place over the last few years. The amount allocated for education in 2017 exceeded 200 billion Saudi Riyals which presented approximately (22\%) of the total budget of the country (Ministry of Finance, 2017). The Ministry of Education, for public education, and the Ministry of Higher Education were incorporated in one ministry called The Ministry of Education in 2015which supervises both public and higher education. Moreover, Education in Saudi Arabia is free from kindergarten to graduate studies, and the government provides public schools with furniture, textbooks, health services, and technological equipment (Alrashidi \& Phan, 2015). As seen in Table 1, the number of public schools has grown from 24,300 in 2009 to 31,841 in 2016 which asserts the noticeable development of education in Saudi Arabia. Moreover, the number of students has \% 
Table 1. Public education statistics

\begin{tabular}{|c|c|c|c|c|c|c|c|c|}
\hline \multirow[t]{3}{*}{ Level } & \multicolumn{4}{|c|}{ Schools } & \multicolumn{4}{|c|}{ Students } \\
\hline & \multicolumn{2}{|c|}{2009} & \multicolumn{2}{|c|}{2016} & \multicolumn{2}{|c|}{2009} & \multicolumn{2}{|c|}{2016} \\
\hline & Male & Female & Male & Female & Male & Female & Male & Female \\
\hline Primary & 5876 & 5735 & 7881 & 7680 & 1137541 & 1044995 & 1411034 & 1434303 \\
\hline Intermediate & 4064 & 3780 & 5056 & 4453 & 625835 & 561669 & 689648 & 651753 \\
\hline Secondary & 2405 & 2440 & 3559 & 3212 & 596419 & 500179 & 675449 & 601085 \\
\hline Subtotals & 12345 & 11955 & 16496 & 15345 & 2359795 & 2267249 & 2776131 & 2687141 \\
\hline Total & 24300 & & 31841 & & 4627044 & & 5463272 & \\
\hline
\end{tabular}

from 4627044 to 5463272 within seven years only (Ministry of Education, 2017).

On the other hand, the government has expanded higher education to meet the increasing number of students graduating from the secondary level every year. Table 2 shows that the number of higher education institutions has increased from 51 in 2009 to 58 in 2016 and the number of students has rapidly grown from 819,012 in 2009 to 1,489,013 in 2016 (Ministry of Education, 2017) as a result of the huge expansion of student acceptance in higher education institutions during the past few years.

\section{Status of ELT in Saudi Arabia}

Unlike the past, the status of English in Saudi Arabia has changed and English language is considered one of the major subjects in the Saudi education system (Rahman \& Alhaisoni, 2013). "English is the only foreign language taught in Saudi schools as part of the mandatory curriculum and therefore enjoys a relatively high status" (Carfax Educational Projects, 2016:10). The Ministry of Education states the aims and objectives of teaching English language in Saudi Arabia as follows: (1) To enable student to acquire basic language skills (listening, speaking, reading and writing). (2) To develop student's awareness of the importance of English as a means of international communication. (3) To develop student's positive attitudes towards learning English. (4) To enable student to acquire the necessary linguistic competence required in various life situations. (5) To enable student to acquire the necessary linguistic competence required in different professions. (6) To develop student's awareness about the cultural, economic, religion and social issues of his society and prepare him to participate in their solutions. (7) To develop the linguistic competence that enables student, in future, to present and explain Islamic concept and issues, and to participate in spreading Islam. (8) To enable student linguistically to benefit from English speaking nations, that would enhance the concepts of international co-operation that would develop understanding and respect of cultural differences between nations. (9) To provide student with the linguistic basis that would enable him to participate in transferring other nations' scientific and technological advances that can enhance the progress of his nation (Rahman \& Alhaisoni, 2013).

At present, English language is taught in Saudi Arabia from the primary $4^{\text {th }}$ grade up to the university level. For the upper three years of the primary stage, time allocated for teaching English is 90 minutes per week divided into two
Table 2. Higher education statistics

\begin{tabular}{|c|c|c|c|c|}
\hline \multirow[t]{2}{*}{ Institutions type } & \multicolumn{2}{|c|}{ Institutions } & \multicolumn{2}{|c|}{ Students } \\
\hline & 2009 & 2016 & 2009 & 2016 \\
\hline $\begin{array}{l}\text { Governmental } \\
\text { Universities }\end{array}$ & 24 & 28 & 784068 & 1400297 \\
\hline $\begin{array}{l}\text { Private Universities } \\
\text { and Colleges }\end{array}$ & 27 & 30 & 34944 & 88716 \\
\hline Total & 51 & 58 & 819012 & 1489013 \\
\hline
\end{tabular}

periods. For the intermediate stage and the secondary stage (Traditional System), English is taught 4 periods a week for a total of 180 minutes. On the other hand, secondary stage students enrolled in the (Credit System) have to study five compulsory English courses (from English 1 to English 5) and each course lasts for a semester through 5 periods a week (225 minutes). Besides, a student may optionally choose one to three English courses if he wants. As seen above, time allocated for teaching English language in public schools is not enough to provide students with the skills needed for communication, reading and writing. At the university level, English language is used as a medium of instruction in some disciplines such as English language, medicine, engineering and the sciences. Besides, it is taught in the foundation year or as compulsory separate courses.

Despite the great efforts and facilities exerted by the government, represented by the Ministry of Education, teaching English in Saudi Arabia is still constant. Although students study English for nine years at schools, they have a low level of achievement and proficienc, face troubles in language skills and rarely communicate properly. Students at universities also have low competency in English language which affect their learning process. Themain causes for low competence in the English language among students include teacher-centered instruction, traditional teaching methodologies, memorization, lack of motivation, lack of practice, customs and culture (Alrashidi\& Phan, 2015). Other barriers to learning English in Saudi Arabia include the introduction of English at a later stage, mother tongue interference, heavy use of L1, shortage of teachers training, the constancy of curriculum and syllabus for long time and lack of Information and communication technology use (Al-Nasser, 2015).Saudi students' English language proficiency is among the worst in the world (Carfax Educational Projects, 2016). According to the EF English Proficiency Index, Saudi Arabia ranks 68 out of 72 countries observed (EF English Proficiency Index, 2017) (Table 3). 
The poor performance of the Saudi students is also confirmed by results of Saudi students in global TOEFL. Saudi TOEFL test-takers rank as the worst in the MENA (MIDDLE EAST/NORTH AFRICA) region. Their scores placed them in the $20^{\text {th }}$ position out of 20 countries in 2016 . Globally, their scores are within the worst 10 percent, 16 percent, 22 percent and 24 percent in the world in writing, reading, listening and speaking respectively. Their overall performance on TOEFL placed them within the $18^{\text {th }}$ percentile, which means that they are amongst the worst 18 percent of scores in the world (Table 4).

Due to the lack of IELTS statistics in 2016, the researcher referred to IELTS scores of 2015 which indicated that Saudi Arabia ranked $39^{\text {th }}$ out of 40 countries monitored by the IELTS on the Academic test performance and $40^{\text {th }}$ out of 40 countries on the General Training test as seen in Tables 5.

As seen above, Saudi students are at the bottom of the list in English proficiency compared to their counterparts all over the world. To some extent, students perform better in speaking and listening more than reading and writing. For the Academic test, the writing was the weakest skill and speaking was the best skill for IELTS test takers. On the other hand, for the General Training test, students were very weak in reading and writing. These aforementioned results are supported by research findings undertaken in the Saudi context over the last few years.

Table 3. Saudi Arabia ranking of English proficiency index EPI (2011 to 2016)

\begin{tabular}{lll}
\hline Year & Ranking & Performance \\
\hline 2011 & 26 out of 44 & Low \\
2012 & 50 out of 52 & Very Low \\
2013 & 59 out of 60 & Very Low \\
2014 & 59 out of 63 & Very Low \\
2015 & 68 out of 70 & Very Low \\
2016 & 68 out of 72 & Very Low \\
\hline
\end{tabular}

Source: (EPI, 2017)

\section{Language Skills of Saudi EFL Students}

The research conducted regarding English language teaching in Saudi Arabia supports the above-mentioned findings. In general, Saudi students have low level of English proficiency and low achievement (Alhawsawi, 2013; Al-Johani, 2009; Al-Khairy, 2013a; Alrabai, 2014; Alrabai, 2016; Alrashidi \& Phan, 2015; Alseweed, 2009; Elyas\& Picard, 2010; Faruk, 2013; Rahman \& Alhaisoni, 2013; Rajab, 2013). About 70\% of Saudi students mentioned that the lower level of their English proficienc is due to the faulty junior and secondary schooling where English would not be taken seriously (Habbash \& Idapalapati, 2016).

Specificall, it has been found that the writing performance of Saudi students was generally poor and they suffer from weakness in writing specially when using grammatical structure (Baka, 2013; Alkubaidi, 2014). Students have numerous writing difficulties in organization, capitalization, vocabulary, grammar, spelling, prepositions, lexical items, syntax, punctuation marks and suffixes and prefixes (Ababneh, 2017; Alhaisoni, Al-Zuoud \& Gaudel, 2015; Althobaiti, 2014; Javid, Farooq \& Umer, 2013; Javid \& Umer, 2014; Raja \& Zahid, 2013; Sawalmeh, 2013; Siddiqui, 2015; Younes \& Albalawi, 2015).Through analyzing their writing samples, Saudi students lack sociolinguistics competence, grammatical competence, strategic competence, and discourse competence (Almubark, 2016).Moreover, Saudi undergraduates are very weak in writing skills and usually engaged in sentence-level or at the maximum at paragraph-level academic writing (Al-Khairy, 2013b). Their writing errors refer to the interference of mother tongue, over-generalization, insufficient activities and practice of basic techniques of writing (Ahmed, 2016;Naikoo, Ganai\& Tawhari, 2016).

Moreover, research indicated an overall low reading comprehension and low reading proficiency among Saudi EFL students (AlAbik, 2014; Al-Qahtani, 2010; Al-Roomy, 2013). Most of Saudi students lack the necessary reading habits (Al-Qahtani, 2016), and they have difficulties in different areas such as use of vocabulary, scanning, skimming,

Table 4. Saudi Arabian students' TOEFL scores (2016)

\begin{tabular}{lccccc}
\hline & Reading & Listening & Speaking & Writing & Total score \\
\hline Saudi Arabia & 14 & 16 & 18 & 15 & 64 \\
MENA average score & 18.1 & 20.15 & 21.45 & 19.85 & 79.8 \\
KSA rank in MENA & 20 out of 20 & 20 out of 20 & 20 out of 20 & 20 out of 20 & 20 out of 20 \\
KSA Global percentile & 16 & 24 & 22 & 10 & 18 \\
\hline
\end{tabular}

Source: (ETS, 2016)

Table 5. Saudi Arabian students' IELTS Academic and general training test performance (2015)

\begin{tabular}{lccccc}
\hline IELTS & Reading & Listening & Speaking & Writing & Total score \\
\hline Academic test performance & 4.8 & 4.9 & 5.5 & 4.6 & 5 \\
Rank Globally & 39 out of 40 & 39 out of 40 & 38 out of 40 & 39 out of 40 & 39 out of 40 \\
General Training test performance & 3.7 & 4.7 & 5 & 4.2 & 4.5 \\
Rank Globally & 40 out of 40 & 40 out of 40 & 40 out of 40 & 40 out of 40 & 40 out of 40 \\
\hline
\end{tabular}

Source: (IELTS, 2016) 
prediction and summarizing (Nezami, 2012). They rarely make use of important reading skills when they read English texts as a result of lack of exposure to the target language, poor teaching skills, little attention to comprehension, lack of motivation, unfamiliar and unsuitable reading topics, lack of reading skills training and limited vocabulary (Al-Qahtani, 2016).

Regarding oral proficienc, it has been found that Saudi students have difficulties in pronouncing certain English consonant sounds(Ahmad, 2011; Hago \& Khan, 2015).Pronunciation, speed of speech, insufficient vocabulary, the different accent of speakers, lack of concentration, anxiety, bad quality of recording, appropriate grammatical structures, hesitance to use the target language, conceptual knowledge, listening ability, motivation to speak, teachers' feedback during speaking activities, confidence, mother tongue, low participation time allow to speak and time allowed for preparation were the major listening comprehension problems encountered by Saudi EFL learners (AlAsmari, 2015; Hamouda, 2013a; Younes \& Albalawi, 2016). This low proficiency is due to many causes such as low English proficienc, fear of speaking in front of others, negative evaluation, shyness, lack of confidence and preparation, and fear of making mistakes (Hamouda, 2013b). Hence, students' speaking performance is mainly affected by four factors that are namely; insufficient input, time for preparation, poor instructions and the unsatisfactory amount of practicing speaking (Younes \& Albalawi, 2016).

Interestingly, a large number of Saudi EFL students fail to understand basic English grammar, suffer from the lack of proper grammar rules in forming various types sentences(Alamin \& Ahmed, 2012; Al-Hassaani, 2016) and have difficulties in many grammatical features (Aljumah, 2011). Of the most important barriers of oral proficienc, using Arabic in class, lack of practicing speaking, devoting more time to listening skills than speaking skills, lack of laboratories for teaching listening and speaking skills, rare use of CD as speaking models. More than 30 students are in listening and speaking class (Hamad, 2013). In concluding, these difficulties are mainly due tointense mother tongue interferences and intralingual interference (Alamin \& Ahmed, 2012; Al-Hassaani, 2016).

\section{Statement of the Problem}

The total number of students in Saudi Arabia reached seven million in 2016. This huge number of students who study English as a foreign language encounter numerous difficu ties and obstacles in acquiring English language skills during their learning period. During the last 10 years, the field of ELT had rapid development, and it is expected that ELT in Saudi Arabia will respond to these developments in order to solve the problems of teaching/learning English language skills that many students face in schools and universities. It is also expected that researchers in Saudi Arabia will benefit from the international trends in ELT to help students overcome frustration and barriers that hinder their effective language skills. Therefore, the current study serves as a basis of teaching/learning language skills in Saudi Arabia since the future research mostly flows from an understanding of the gaps, inconsistencies, intellectual problems, and controversies emerging from the feasible areas of the current literature (Murrey \& Beglar, 2009). Consequently, it is important to conduct a thorough analysis of the previous research on teaching/learning language skills in Saudi Arabia to understand the development of language research during the past ten years in order to be able to have a clear image of the appropriate and inappropriate directions applied in Saudi Arabia to solve the problems of gaining language skills among Saudi EFL students. This study first provides a literature review on ELT in the Saudi context. Then, it examines trends in the teaching/learning of language skills in Saudi Arabia by systematically analyzing the previous studies on language skills which were published within the past ten years. Finally, it presents the future research areas to fill the gaps in teaching/learning language skills in Saudi Arabia.

\section{The objectives of the Systematic Review}

The main objectives of this systematic review were to:

1. Present the current status of research on language skills of Saudi EFL students between 2007 and 2016.

2. Investigate the contribution of those studies in improving the language skills of EFL students in Saudi Arabia.

3. Identify the language skills research gaps and where further research should be carried out.

\section{Research Questions}

1. What studies have been undertaken on language skills of Saudi EFL students between 2007 and 2016?

2. How do those studies contribute to improve language skills of Saudi EFL students?

3. What are the particular points that need to be taken into consideration for future research on the language skills of Saudi EFL students?

\section{RESEARCH METHODOLOGY}

The current study employed the systematic review method. A systematic review is a summary of the research literature on a single situation to identify, select, appraise and synthesize all high-quality research evidence relevant to that situation (Bettany-Saltikov, 2012). "Good systematic review sample sufficient precautions to minimize error and bias" (Littell, Corcoran \& Pillai, 2008:1). A systematic review follows a well-defined protocol, that indicates objectives, concepts, and procedures in advance, to synthesize the available research to arrive at reliable conclusions (Lau, 2007).After developing the research questions, the review protocol was established to search for the relevant studies.

\section{Search Strategy for Systematic Map Studies}

This step aimed at identifying the most relevant databases for this systematic review. The search was conducted using different databases including ERIC, Google Scholar, Wiley Online Library, Web of Science, Taylor \& Francis, Sprin- 
gerLink-Springer, Scopus-Elsevier, Sage Journals-Sage, EduSearch and Saudi Digital Library. Different research strategies were tested, including reviewing the abstracts, adding/deleting different research terms (variants, synonyms, hyponyms) and manual searching. A specific set of research terms was selected to yield the most appropriate results in both English and Arabic languages as seen in Table 6. The terms were searched using "OR" function for each column and "AND" function for each row. For example, "Saudi Arabia" "AND" "English" "AND" "Listening" "AND" "Learning" was used for the first search and "Saudi" "AND" "English" "AND" "Listening" "AND" "Learning" was used for the second search and so on until all conjunctions of terms were used. Searches were done by two independent reviewers (the author and a specialist in ELT) to assure reliability.

\section{Inclusion/Exclusion Criteria}

After carrying out the initial search strategy, the studies to be included in the keyword map were identified according to the following inclusion and exclusion criteria:

\section{Inclusion criteria}

Studies were included if:

1. They were conducted in Saudi Arabia.

2. They focused on language skills.

3. They were published between 2007 and 2016 .

4. They were peer-reviewed journal publications.

5. They were not obtainable in full-text form

6. They covered any of these educational settings (public schools or universities).

\section{Exclusion criteria}

Studies were excluded if:

1. They were not conducted in Saudi Arabia.

2. They did not focus on language skills.

3. They were published before 2007 or after 2016

4. They were not peer-reviewed journal publications
5. They had an inappropriate methodology.

6. They focused on industrial and/or vocational students. Using PRISMA checklist. The search strategy generated 1438 studies which were reduced to 983 studies after duplicates removed. After records screened, 522 studies were excluded, resulting in 461 full-text articles. Then those fulltext articles were assessed against the above-mentioned inclusion/exclusion criteria resulting in the exclusion of 238 studies. This search strategy yielded 221 studies for inclusion in the systematic keyword map.

\section{In-depth Review Studies}

Two independent reviewers read each study in depth. They compared their findings and resolved any differences. For the in-depth synthesis, additional criteria were applied:

Studies were excluded for in-depth review if:

1. They focused on teachers' performance or behaviors in teaching language skills.

2. They focused on variables not directly related to language skills.

3. They focused on general achievement.

The application of these three additional criteria yielded 95 studies which were included in the in-depth review (Figure 1).

\section{RESULTS AND DISCUSSION}

\section{Studies Included in Systematic Map Review}

This section focuses on the systematic map review to describe the relevant studies to answer the first research question: "What studies have been undertaken on language skills of Saudi EFL students between 2007 and 2016?" (Table 7).

Almost all of the included studies were published in English language (93.67\%), whereas only $(6.33 \%)$ were published in Arabia language. This explains researchers' desire to use English language when conducting their ELT research (Table 8).

The majority of included studies were published in foreign journals $(73.30 \%)$, while $(16.74 \%)$ of the studies were

Table 6. Keyword search terms

\begin{tabular}{|c|c|c|c|c|c|c|c|}
\hline Saudi Arabia & AND & English & AND & Listening & & AND & Learning \\
\hline OR & & OR & & OR & Speaking & & OR \\
\hline \multirow[t]{11}{*}{ Saudi } & & Language & & OR & Reading & & Teaching \\
\hline & & & & OR & Writing & & \\
\hline & & & & OR & Grammar & & \\
\hline & & & & OR & Vocabulary & & \\
\hline & & & & OR & Pronunciation & & \\
\hline & & & & OR & Oral & & \\
\hline & & & & OR & Linguistic & & \\
\hline & & & & OR & Skill & & \\
\hline & & & & OR & Communication & & \\
\hline & & & & OR & Achievement & & \\
\hline & & & & OR & Proficienc & & \\
\hline
\end{tabular}




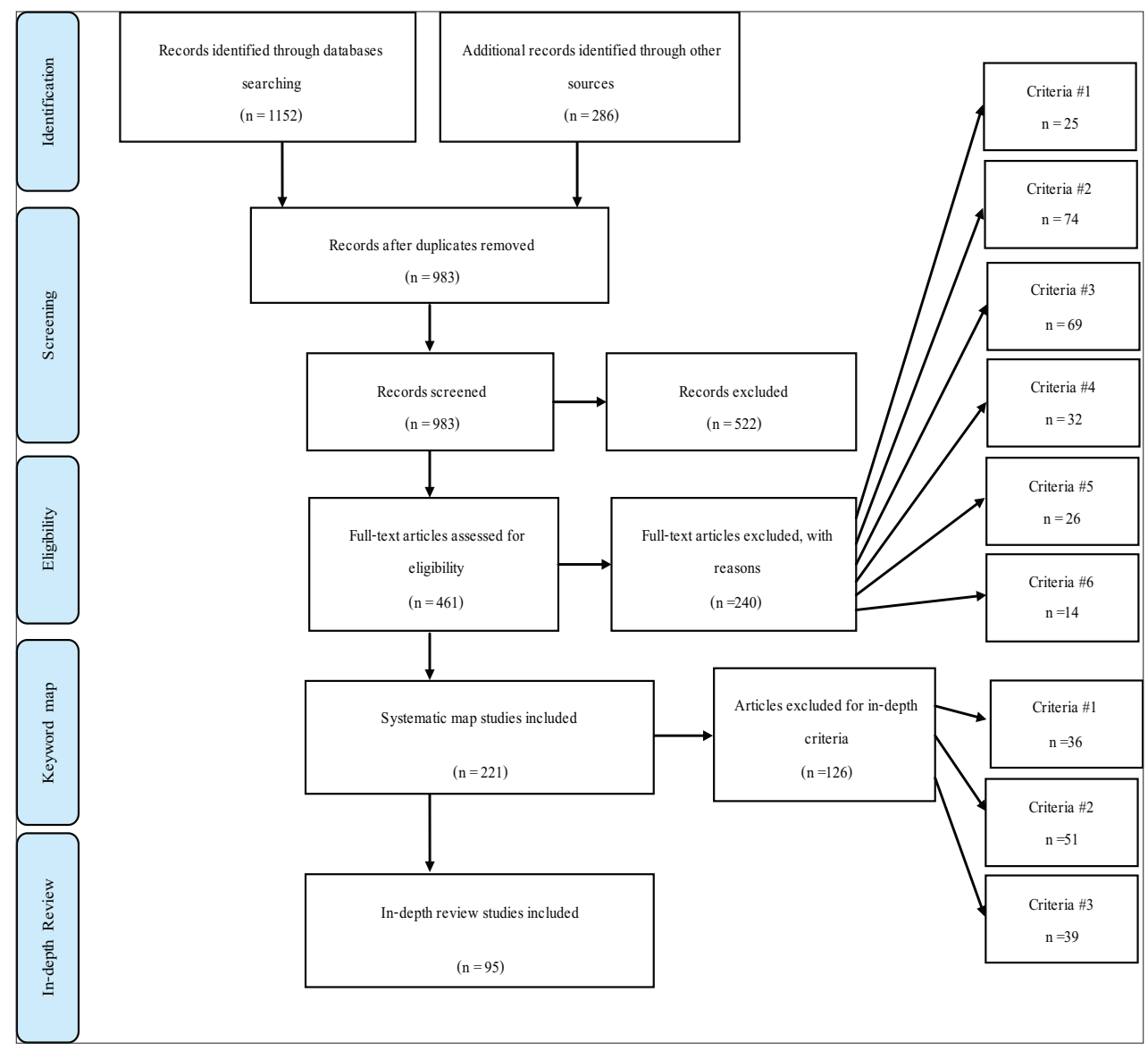

Figure 1. PRISMA flow diagra

Table 7. Language of included studies

\begin{tabular}{lcc}
\hline Language & Number & Percentage \\
\hline English & 207 & 93.67 \\
Arabic & 14 & 6.33 \\
Total & 221 & 100 \\
\hline
\end{tabular}

Table 8. Types of journals published included studies

\begin{tabular}{lcc}
\hline Journals & Number & Percentage \\
\hline Foreign & 162 & 73.30 \\
Arab & 37 & 16.74 \\
Saudi & 22 & 9.96 \\
Total & 221 & 100 \\
\hline
\end{tabular}

Table 9. Number of authors

\begin{tabular}{lcc}
\hline Number of author (s) & Number & Percentage \\
\hline One author & 148 & 66.97 \\
Two authors & 60 & 27.15 \\
Three authors or more & 13 & 5.88 \\
Total & 221 & 100 \\
\hline
\end{tabular}

published in Arab journals. The minority of studies were published in Saudi journals (9.96\%). This shows that Saudi journals do not contribute appropriately in publishing ELT research which is due to scarcity of specialized journals in the field of $\mathrm{E} T$.

Table 9 illustrates that $(66.97 \%)$ of included studies was conducted by only one author, followed by $(27.15 \%)$ conducted by two authors, and a small proportion was conducted by three or more authors. It is clear that researchers of ELT in Saudi Arabia almost lack cooperation when conducting ELT research.

The majority of included studies $(68.32 \%)$ were conducted by male authors, while only (23.08\%) were conducted by females, and only $(8.60 \%)$ of the authors were mixed-gender. This indicates that most of the research of ELT in Saudi Arabia were conducted on male students or teachers, and the minority of research were conducted on female students or teachers.

Almost half of the included studies were conducted by Saudi researchers $(54.75 \%)$, followed by $(33.94 \%)$ conducted by non-Saudi authors, and a small percentage (11.31\%) were conducted by Saudi and non-Saudi authors. This illustrates the growth of Saudi ELT faculty members in the past few years as a result of the existence of qualified Saudi researchers in ELT.

The majority of included studies employed the quantitative methodology $(81.45 \%)$, whereas only $(6.33 \%)$ employed the qualitative methodology, and (12.22\%) used mixed-method approach. This finding shows that most of the researchers prefer the qualitative method since it easier to apply. One of the most important limitation of using the 
qualitative method is that it does not give a deep insight of the phenomenon being studied. Therefore, ELT researchers in Saudi Arabia should use the qualitative method in accordance with the qualitative method in order to have more consistent results.

Table 13 shows that $(59.44 \%)$ of the quantitative studies were quasi-experimental, $(35.56 \%)$ were descriptive in nature, and only ( $5 \%$ ) were correlational studies.

The majority of the included studies utilized only one instrument $(54.75 \%)$, while $(31.22 \%)$ of included studies used two instruments. Three instruments were applied in only $(10.41 \%)$ of the included studies, and four or more instruments were used in a small proportion (3.62\%).Researchers should use more than one instrument to collect as much data as possible on the subject of the study.

Table 15 illustrates that the sample of $(80.09 \%)$ of included studies were students, followed by students and teachers with $(10.41 \%)$, and only $(9.50 \%)$ were teacher-sampling. It is clear that students with special needs were almost neglected when conducting studies. Only four studies out of 221 were conducted on those students representing only (2.26\%).

The majority of the participants were only male, representing almost half of the studies conducted $(51.13 \%)$, followed by an almost quarter of the studies (24.43\%) con-

AQ1 Table 10. Gender of authors

\begin{tabular}{lcc}
\hline Gender of author $(\mathbf{s})$ & Number & Percentage \\
\hline Male & 151 & 68.32 \\
Female & 51 & 23.08 \\
Mixed & 19 & 8.60 \\
Total & 221 & 100
\end{tabular}

AQ1 Table 11. Nationality of authors

\begin{tabular}{lcc}
\hline Nationality of author (s) & Number & Percentage \\
\hline Saudi & 121 & 54.75 \\
Non-Saudi & 75 & 33.94 \\
Mixed & 25 & 11.31 \\
Total & 221 & 100 \\
\hline
\end{tabular}

AQ1 Table 12. Methodologies of included studies

\begin{tabular}{lcc}
\hline Methodology & Number & Percentage \\
\hline Quantitative & 180 & 81.45 \\
Qualitative & 14 & 6.33 \\
Mixed & 27 & 12.22 \\
Total & 221 & 100 \\
\hline
\end{tabular}

Table 13. Designs of the quantitative studies

\begin{tabular}{lcc}
\hline Designs & Number & Percentage \\
\hline Quasi-experimental & 107 & 59.44 \\
Descriptive & 64 & 35.56 \\
Correlational & 9 & 5.00 \\
Total & 180 & 100 \\
\hline
\end{tabular}

ducted on females only. About (19\%) of the studies were conducted with mixed students, and finally (5.44\%) were not specified. More research should be conducted on female samples because they present almost $50 \%$ of the total students in Saudi Arabia.

Table 17 shows that:

1. There was a significant increase of studies from 2007 to 2016. Between 2007 and 2011, there were only (48 studies; $21.72 \%$ ), while 173 studies $(78.28 \%$ ) were conducted within the past five years

2. About three-quarters of the studies were conducted at the university level (162 studies; $73.30 \%$ ), while only (59 studies; $26.7 \%$ ) were conducted at the school level from kindergarten to secondary level. There was more interest in conducting studies at the university level since most of the researchers were faculty members and it was easy for them to conduct their studies at universities rather than schools. This tendency prevents school students from participating in those studies, and consequently, their language skills problems are almost neglected.

3. Within schools, it was clear that most concentration was devoted to secondary level students and teachers with (13.12\%), and only (10.87\%) was devoted to students and teachers from kindergarten to intermediate.

Majority of included studies (31.22\%) was conducted on the strategies used in teaching and learning of language skills, followed by $(21.72 \%)$ which were conducted regarding the use of technology in general and CALL in particular in teaching/learning language skills. Difficulties of language

Table 14. Number of instruments

\begin{tabular}{lcc}
\hline Number of instruments & Number & Percentage \\
\hline One instrument & 121 & 54.75 \\
Two instruments & 69 & 31.22 \\
Three instruments & 23 & 10.41 \\
Four or more instruments & 8 & 3.62 \\
Total & 221 & 100 \\
\hline
\end{tabular}

Table 15. Sampling

\begin{tabular}{lcc}
\hline Sampling & Number & Percentage \\
\hline Students & $177^{*}$ & 80.09 \\
Teachers & 21 & 9.50 \\
Students and teachers & 23 & 10.41 \\
Total & 221 & 100 \\
\hline
\end{tabular}

(*) For student samples, only 4 studies out of 177 dealt with special needs students $(2.26 \%)$.

Table 16. Gender of participants

\begin{tabular}{lcc}
\hline Gender & Number & Percentage \\
\hline Male & 113 & 51.13 \\
Female & 54 & 24.43 \\
Mixed & 42 & 19.00 \\
Not specified & 12 & 5.44 \\
Total & 221 & 100 \\
\hline
\end{tabular}


Table 17. Studies by year of publication and education level (K=Kindergarten, $P=$ Primary, $\mathrm{I}=$ Intermediate, $\mathrm{S}=$ Secondary, ASL=All School Levels, U=University)

\begin{tabular}{|c|c|c|c|c|c|c|c|c|}
\hline Year & $\mathbf{K}$ & $\mathbf{P}$ & I & $\mathbf{S}$ & ASL & $\mathbf{U}$ & Total & $\%$ \\
\hline 2007 & - & 1 & - & 2 & - & 2 & 5 & 2.26 \\
\hline 2008 & - & - & - & 3 & - & 5 & 8 & 3.62 \\
\hline 2009 & - & - & - & - & - & 3 & 3 & 1.36 \\
\hline 2010 & - & 1 & - & 6 & & 6 & 13 & 5.88 \\
\hline 2011 & - & - & - & - & 1 & 18 & 19 & 8.60 \\
\hline 2012 & - & - & - & 2 & - & 25 & 27 & 12.22 \\
\hline 2013 & 1 & 2 & - & 3 & 1 & 22 & 29 & 13.12 \\
\hline 2014 & 1 & 1 & 4 & 5 & 3 & 29 & 43 & 19.46 \\
\hline 2015 & - & 4 & 6 & 6 & 1 & 27 & 44 & 19.91 \\
\hline 2016 & 1 & 1 & 1 & 2 & - & 25 & 30 & 13.57 \\
\hline Total & 3 & 10 & 11 & 29 & 6 & 162 & 221 & 100 \\
\hline$\%$ & 1.36 & 4.53 & 4.98 & 13.12 & 2.71 & 73.30 & 100 & \\
\hline
\end{tabular}

AQ1 Table 18. Studies by subject matter used in language skills research

\begin{tabular}{lcc}
\hline Category & Number & Percentage \\
\hline $\begin{array}{l}\text { Teaching/learning Language skills } \\
\text { strategies }\end{array}$ & 69 & 31.22 \\
Technology and CALL & 48 & 21.72 \\
Difficulties of Language skills & 41 & 18.55 \\
Students' perceptions on & 23 & 10.41 \\
Language skill & & \\
Mobile learning & 14 & 6.33 \\
Beliefs and attitudes towards & 11 & 4.98 \\
Language skills & & \\
Teachers' performance on & 7 & 3.17 \\
Language skills & & \\
Impact of L1 on Language skills & 4 & 1.81 \\
Social media & 4 & 1.81 \\
Total & 221 & 100 \\
\hline
\end{tabular}

AQ1 Table 19. Systematic map studies by language skills ( $\mathrm{N}=221$, not mutually exclusive)

\begin{tabular}{lcc}
\hline Category & Number & Percentage \\
\hline Writing & 66 & 28.09 \\
Reading & 56 & 23.83 \\
Proficiency and achievement & 39 & 16.60 \\
Vocabulary & 26 & 11.06 \\
Speaking & 22 & 9.36 \\
Listening & 11 & 4.68 \\
Grammar & 8 & 3.40 \\
Pronunciation & 7 & 2.98 \\
Total & 235 & 100 \\
\hline
\end{tabular}

skills represented (18.55\%) of included studies, while students' perceptions on language skill gained (10.41\%). Mobile learning was used in language skills research with (6.33\%), and only (4.98\%) was devoted to the beliefs and attitudes towards language skills. A minority of included studies was conducted on teachers' performance on language skills, the impact of L1 on language skills and the use of social media with $(3.17 \%),(1.81 \%)$ and $(1.81 \%)$ respectively.

The largest number of studies focused on writing (28.09\%) and reading $(23.83 \%)$. Then proficiency and achievement of language skill represented $(16.60 \%)$ of included studies. After that vocabulary came with $(11.06 \%)$, speaking $(9.36 \%)$, listening $(4.68 \%)$, grammar $(3.40 \%)$ and finall , pronunciation $(2.98 \%)$. It was clear that about $(70 \%)$ of the studies focused on writing, reading and general achievement, whereas approximately $(30 \%)$ focused on vocabulary, speaking, listening, grammar and pronunciation together. There was a lack of studies that addressed the latter skills, whereby, the need for more studies on those skills arises.

\section{The In-depth Review}

This section focuses on the in-depth review to answer the second research question: "How do those studies contribute to improve language skills of Saudi EFL students?" and the third question: "What are the particular points that need to be taken into consideration for future research on the language skills of Saudi EFL students?".

Ninety-five studies from the systematic map review were included in the in-depth review. Some of the studies investigated more than one skill.

The majority of studies investigated writing skill (32 studies; 30.47\%), reading skill (28 studies; 26.67\%), vocabulary (16 studies; 15.24\%) and speaking skill (14 studies; $13.33 \%)$. Only 7 studies (6.67\%) investigated listening skill, 6 studies $(5.71 \%)$ for grammar, and finally 2 studies (1.91\%) for pronunciation. As seen in Table 20, most of the studies were conducted from 2012 to 2015 (80 studies; 76.19\%) which indicated a significant growth of language skill studies in the Saudi context during the past few years.

Table 21 illustrates that most of the in-depth studies were conducted at the university level (64 studies; 67.36\%), fol- 
Table 20. In-depth review studies by language skills ( $\mathrm{N}=95$, not mutually exclusive)

\begin{tabular}{lcccccccccccc}
\hline Category & $\mathbf{2 0 0 7}$ & $\mathbf{2 0 0 8}$ & $\mathbf{2 0 0 9}$ & $\mathbf{2 0 1 0}$ & $\mathbf{2 0 1 1}$ & $\mathbf{2 0 1 2}$ & $\mathbf{2 0 1 3}$ & $\mathbf{2 0 1 4}$ & $\mathbf{2 0 1 5}$ & $\mathbf{2 0 1 6}$ & Total & Percentage \\
\hline Writing & - & 2 & - & 1 & 2 & 8 & 2 & 7 & 9 & 1 & 32 & 30.47 \\
Reading & - & - & - & 1 & 1 & 2 & 4 & 6 & 9 & 5 & 28 & 26.67 \\
Vocabulary & 1 & - & - & - & - & 1 & 3 & 1 & 8 & 2 & 16 & 15.24 \\
Speaking & - & 1 & - & 1 & - & 4 & 3 & 2 & 2 & 1 & 14 & 13.33 \\
Listening & - & - & - & 2 & - & 4 & 1 & - & - & - & 7 & 6.67 \\
Grammar & - & - & - & 1 & 1 & - & - & 1 & 2 & 1 & 6 & 5.71 \\
Pronunciation & - & - & - & 1 & - & - & - & 1 & - & - & 2 & 1.91 \\
Total & 1 & 3 & - & 7 & 4 & 19 & 13 & 18 & 30 & 10 & 105 & 100 \\
\hline
\end{tabular}

lowed by secondary, intermediate, primary and finally kindergarten with only 2 studies $(2.11 \%)$. As known, language skills grow from childhood, but the studies at this level were rare which indicated the importance of conducting more studies at primary and intermediate levels.

The studies included in the in-depth review were classified according to language skills as writing, reading, listening, speaking, vocabulary, grammar and pronunciation.

\section{Writing skill}

Thirty-three studies investigated writing skills of Saudi EFL students. Those studies were analyzed in-depth to summarize the most important findings

Table 22 illustrates that almost half of the studies (46.87\%) were conducted on the writing problems and difficulties that Saudi EFL students face, followed by using technology and social media in writing $(28.12 \%)$, teaching strategies (15.63\%), and finally Mobile learning with only (9.38\%). These findings indicated the lack of searching for a solution to writing problems which could be helpful in teaching writing skill since only five studies experimented writing teaching strategies.

The studies of writing problems were all conducted at university level neglecting the importance of conducted similar studies at school level in which students had several writing problems. Three studies of the total writing studies concentrated on spelling error (Albalawi, 2016; Alhaisoni et al., 2015; Hameed, 2016), two studies explored essay writing problems (Naikoo et al., 2016; Sawalmeh,2013), one study dealt with syntactical and punctuation errors (Alamin, 2012) and one investigated capitalization errors (Siddiqui, 2015). The remaining studies focused on writing problems in general. Studies review indicated that spelling errors of Saudi EFL students were errors of omission, wrong use of vowels, transportation spelling errors, diphthongs and silent letter words. Two of the three studies were conducted in the same year and had identical findings which meant that some researchers did not look for research gaps to make their research supportive of other research. Moreover, the two studies which investigated essay and paragraph writing errors included copula, concord, number, tense markers, prepositions, articles, conjunctions, word order, singular/plural form, subject-verb agreement, double negatives, spellings, capitalization, articles and sentence fragments were the most
Table 21. In-depth studies by education sector

\begin{tabular}{lcc}
\hline Education sector & Number & Percentage \\
\hline University & 64 & 67.36 \\
Secondary & 18 & 18.95 \\
Intermediate & 6 & 6.32 \\
Primary & 5 & 5.26 \\
Kindergarten & 2 & 2.11 \\
Total & 95 & 100 \\
\hline
\end{tabular}

Table 22. In-depth studies by research field

\begin{tabular}{lcc}
\hline Category & Number & Percentage \\
\hline Writing problems & 15 & 46.87 \\
Technology and social media & 9 & 28.12 \\
Teaching strategies & 5 & 15.63 \\
Mobile learning & 3 & 9.38 \\
Total & 32 & 100 \\
\hline
\end{tabular}

common errors among Saudi EFL students, but both studies did not suggest solutions to the aforementioned problems andneither further research to bridge this gap.

From 2013 to 2016, eight studies investigated writing problems of Saudi EFL students in general. The findings of these studies were almost identical. They showed that Saudi EFL students were very weak in writing skills and committed lots of errors in their writings. They had serious problems in their writing due to many factors such as mother tongue interference, besides insufficient activities and practice of basic techniques of writing in addition to the lack of follow-up to the students' writing performance. Although many writing problems among Saudi EFL students were discovered, almost no studies were conducted to solve those problems empirically since most of the studies conducted were exploratory ones that ended in investigating the problem without giving accurate further research recommendations to be followed by future researchers.

On the other hand, technology use in teaching writing was investigated in nine studies. All nine studies were conducted at the university level; no single study was applied to school level students although technology and social media are widely implemented at the school level. The most frequently used technologies were Wikis and Blogs. Four 
Table 23. In-depth studies by research field

\begin{tabular}{lcc}
\hline Category & Number & Percentage \\
\hline Teaching strategies & 13 & 46.43 \\
Technology and social media & 10 & 35.71 \\
Reading problems & 3 & 10.72 \\
Mobile learning & 2 & 7.14 \\
Total & 28 & 100 \\
\hline
\end{tabular}

studies applied "Wiki", whereas WebQuest, Online checker, WEB and Twitter were used once in three studies. The findings of all those studies indicated that Web 2.00 technology was effective in teaching writing skills. Surprisingly, female students participated in only three studies; two of them were conducted by one researcher (Grami, 2012; Grami \& Alkazemi, 2016). This indicated that technology must be investigated more with females and mixed-gender students. Although many technologies and social media has emerged in the last decade, most of them were not experimented in teaching writing such as YouTube, Facebook, webcasts, Myspace, Flicker and so on.

From in-depth studies review, only five studies experimented teaching strategies from 2007 until 2016. Those strategies were Journal Writing, Dialogue Journal, Self-Regulated Strategy Development, Visualization and Discourse Markers. Three of those five interventions were conducted at the university level while only two interventions were applied to primary and secondary students. It is noticed that the studies that experimented strategies in teaching writing skills were limited although there were lots of strategies which could be used to improve writing skills. So, researchers are advised to bridge this gap by experimenting new strategies, especially at earlier stages of schooling, to improve teaching writing to young students and never wait until they move to higher education.

Finally, three studies included in the in-depth review investigated the effect of mobile learning in teaching writing skills. Hence, three applications, namely, Podcasting, SMS and WhatsApp were used. All studies were conducted a the university level and the participants were male only. The findings of all studies revealed a significant effect on students' writing skills. There was a limitation in two studies (AbdulFattah, 2015; Mahmoud, 2013), due to the small samples used. So the findings might not be generalized to the populations of the studies. Moreover, mobile learning was used in the above-mentioned two studies as an alternative means of traditional teaching, and not as a method that could be assessed. More studies in this research area must be undertaken employing larger random samples to clearly investigate the effect of mobile learning in teaching writing skills.

\section{Reading skill}

The in-depth review included twenty-seven studies which investigated reading skills of Saudi EFL students. Twenty-four of them were conducted from 2013 to 2016.

Table 23 shows that almost half of the studies (46.43\%) investigated using teaching strategies to develop reading skills. Technology and social media represented a consider- able percentage $(35.71 \%)$ in teaching reading, followed by investigating reading problems $(10.72 \%)$ and finally utilizing mobile learning with $(7.14 \%)$.

Thirteen studies investigated the effect of different teaching strategies on reading skills. Those strategies included Metacognitive reading strategies (3 studies), "3-2-1" reading strategy, expansion of vision span, textual discourse markers, schema-based techniques, self-managed strategies, creative circles, multiple intelligences activities, exploration and thinking loudly strategies, talking story books and word walls. Moreover, the participants of five studies were university students, followed by secondary and intermediate (3 studies) for each level, then primary and kindergarten (1 study) each. It is noticed again that university students gained the highest interest. Much interest is supposed to be devoted to lower level students and to poor reader students who suffered from serious reading difficulties

Moreover, ten studies investigated the effect of technology and social media on learning the reading skill. Most of the studies ( 8 studies) were conducted at the university level with exception of two studies; one for primary and one for secondary level. The most frequently used technologies were Wikis, Blogs and WebQuest. Other technologies included flash professional, smart classrooms, computer-based concept maps and Twitter. All findings indicated that using technology yielded an improvement in students' reading skills. Thus, there was a limited use of technologies in teaching reading skills since there are lots of applications that can be used effectively in this area. Astonishingly, all the ten studies were conducted on male students only which indicated the ignoring of female students in benefiting from technology applications to improve their performance in reading skill.

Although Saudi EFL students face many serious problems in learning reading skills as mentioned earlier, a limited number of studies was conducted in this research area. Of the 95 studies included in the in-depth review, only three studies tackled this problem. In general, the main findings of those limited studies indicated that Saudi EFL students had difficulties in reading such as the use of limited of vocabulary, scanning, skimming, prediction, summarizing and lack of exposure to the target language. There is a demand for more studies in this area to identify more reading problems and try to find solutions to overcome those difficulties. In addition, an amazing finding was that all participants of those studies were male; no female students participated in any study dealing with reading problems. It is obvious that more interest has to be directed to fill this research gap by investigating female students reading problems since gender may have an impact on the findings of the mentioned studies.

Finally, only two studies investigated the effect of mobile learning on reading skills. They were conducted in 2016. One of them applied WhatsApp to exchange information regarding reading passages and used mobile as a means of introducing information, but not as a learning tool. The other study applied Augmented Reality applications to be used in class to improve students' reading skills. Both interventions showed significant improvements in students' reading comprehension. This review indicated that much applications of 
mobile learning should be experimented for both male and female students at all levels of education.

\section{Listening skill}

Between 2007 and 2016, only seven studies were conducted on listening skills. Although listening is one of the most important skills of language learning, the number of studies conducted is still very limited.

As seen in Table 24, most of the studies (42.86\%) investigated using technology in teaching listening skills. Only two studies discussed the problems of learning listening skills $(28.57 \%)$. Finally, one study experimented a teaching strategy, and another one experimented applying mobile learning to develop listening skills.

Simulation, multi-media software and MOOC'S technologies were implemented in three studies at secondary and university levels between 2011 and 2014. The findings of those studies were contradictory to some extent (Al-Hammadi, 2011, Freihat \& AlZamil, 2014; Javid, 2013).During the last two years, no studies were conducted regarding using technology in teaching listening skills although many applications emerged during the few past years. Teaching listening with technology at schools level needs more research since listening is taught by Saudi teachers who must expose students to texts spoken by English native speakers to improve students listening skills.

On the other hand, only two studies investigated the listening difficulties that Saudi EFL students face (Alenazi, 2013; Hamouda, 2013a). Those two studies were only undertaken at the university level in one year. Those studies showed that university students had serious problems in listening skills such as accent, pronunciation, speed of speech, insufficient vocabulary, different accent of speakers, lack of concentration, anxiety, bad quality of recording, teacher's techniques of teaching, English sound system, English words meaning, memory and attention, topic of the lecture, learner's strategies of learning, tasks and activities of listening, listener, the environment surrounding the listener, and the emotional and psychological side of the listener. Although several problems were identified, no later studies contributed in solving those problems. As seen above, there is a research gap in conducting studies at the school level and studies that find solutions to those problems

Lastly, there was a single study conducted in 2011 to experiment a strategy (the communicative approach), and it was effective in improving secondary school students' listening skills. In addition, mobile learning was also implemented in a single study in 2013 and found effective in learning listening skills. Researcher are recommended to try more effective teaching strategies and invest mobile learning applications, which are available to students, in teaching listening skills in the future.

\section{Speaking skill}

Regarding speaking skill, fourteen studies were undertaken between 2007 and 2016 on Saudi EFL students.

Table 25 shows that (5 studies; $35.72 \%$ ) investigated fiv different teaching strategies used to develop students' speaking skills, followed by (4 studies; $28.57 \%$ ) on speaking problems of Saudi EFL students, (4 studies; 28.57\%) on using technology and finally one study (7.14\%) on using mobile learning

The findings showed that researchers experimented five different teaching strategies namely; concept mapping, drama, structural discourse markers, task repetition and the communicative approach. These strategies were all effective and had a positive effect on students' speaking skills. Only two of those studies were conducted on female students which indicates the need for more research on female students in the future. Moreover, four of those studies were conducted at university level which makes the need for conducting studies on school level students since they need more interest to improve their speaking skills at early stages.

Next, four out of those fourteen studies investigated speaking problems of Saudi EFL students. The finding showed many problems and difficulties such as using Arabic language in class, fear of speaking English language in public, lack of laboratories and CDs, inability to command proper pronunciation, lack of appropriate grammatical structures and necessary vocabulary items, fear of criticism, the disability to think of anything to say and speaking very little during class. All those studies were conducted on university level students and the participants of three of them were female students. These findings point out that male students speaking difficulties were almost neglected during the past ten years. Speaking difficulties of school level students were neglected too which shows two main research gaps in these areas.

Moreover, technologies were used in teaching speaking skills in four studies only (Alharbi, 2014; AlJiffri, 2009; Alshahrani,2016; Javid, 2013). The findings of those studies were conflictin which requires more research in this area. Also, most of those studies were conducted on male students which again requires paying more attention to involve female students in technology research.

Finally, only one study was conducted on the use of mobile learning in teaching speaking skill. That study experimented using SMS which was really not an appropriate application for teaching that kind of skill. More investigations

Table 24. In-depth studies by research field

\begin{tabular}{lcc}
\hline Category & Number & Percentage \\
\hline Technology & 3 & 42.86 \\
Listening problems & 2 & 28.57 \\
Teaching strategies & 1 & 14.28 \\
Mobile learning & 1 & 14.29 \\
Total & 7 & 100 \\
\hline
\end{tabular}

Table 25. In-depth studies by research field

\begin{tabular}{lcc}
\hline Category & Number & Percentage \\
\hline Teaching strategies & 5 & 35.72 \\
Speaking problems & 4 & 28.57 \\
Technology & 4 & 28.57 \\
Mobile learning & 1 & 7.14 \\
Total & 14 & 100 \\
\hline
\end{tabular}


are expected in the future to experiment more applications of mobile learning in teaching speaking skills due to the emergence of mobile applications in the past few years.

\section{Vocabulary}

From 2007 to 2016, sixteen studies were conducted on teaching/learning vocabulary. Ten of those studies were undertaken during the past two years.

Table 26 shows that using technology in teaching vocabulary came first ( 7 studies; $43.75 \%$ ), then (6 studies; $37.50 \%$ ) investigated different teaching strategies to develop students' vocabulary, followed by (2 studies; $12.50 \%$ ) on vocabulary problems that faced Saudi EFL students, and finally one study $(7.14 \%)$ on using mobile learning.

Effects of different technology tools were widely investigated in teaching vocabulary. The seven studies implemented multimedia (2 studies),online tools, video games, synchronization, simulation and smart classrooms. The findings showed that technology was effective in vocabulary learning. Moreover, those studies were undertaken at almost all levels of education, and male and female students participated in those studies. More studies are required at primary and intermediate levels since these levels affect the acquisition of vocabulary and help students gain more vocabulary at early stages.

Regarding vocabulary teaching strategies, only six strategies were experimented. Most of them focused on secondary and university students. The findings of those studies proved their effect on vocabulary learning. But the number of studies was limited since students had inadequate vocabulary items even though at the university level. Researchers have to conduct more studies on vocabulary teaching strategies at kindergarten and primary levels to increase their vocabulary items due to the fact that more vocabulary leads to better learning of the language in general.

In addition, only two studies were conducted regarding the difficulties of vocabulary learning and the impact of L1 on second language vocabulary learning. The findings of both studies were not decisive enough in this area. As Saudi EFL students have limited vocabulary items, there is a crucial necessity to conduct more studies to explore the difficulties that students face in vocabulary learning and to find practical solutions to these difficulties

Lastly, only one study was conducted on using mobile learning in vocabulary learning although mobile learning has many beneficia applications which can be used especially for vocabulary learning. More studies are required in this field since more than 775,000 applications were available in the beginning of 2013 that have the potential to help learners get immediate learning in new ways that have never happened before (Deng \& Trainin, 2015).

\section{Grammar}

Grammar had inadequate interest during the past ten years. Only six studies were conducted at different education levels.

Table 27 illustrates that using technology in teaching grammar, using teaching strategies and grammar difficulties had similar interest with two studies for each category.
Two studies were conducted on secondary school male students using E-learning and synchronization technology. Female students did not participate in any research concerning the use of technology in learning grammar. Moreover, two studies were conducted on grammar difficulties and the impact of using L1 in teaching L2 grammar. They found that students had many difficulties in learning grammatical rules and using L1 in teaching L2 grammar did not benefit the students. In addition, two teaching strategies were experimented in teaching grammar; flippe classroom which was ineffective and constructive learning strategies effective in learning grammar rules. The findings showed that female students participated in only two studies which require paying more attention to this research gap. Another finding was the noticeable limit of grammar research during the past ten years. More research is required at all education levels to investigate the problems that Saudi EFL students face in learning grammatical rules and structure. Furthermore, more experimental interventions are necessary to experiment new strategies in this research area.

\section{Pronunciation}

Pronunciation had the least interest in the other skills of English language in Saudi Arabia. Only two studies were conducted at secondary and university levels.

Table 28 illustrates that only two studies were conducted regarding the pronunciation of Saudi EFL students. Both

Table 26. In-depth studies by research field

\begin{tabular}{lcc}
\hline Category & Number & Percentage \\
\hline Technology & 7 & 43.75 \\
Teaching strategies & 6 & 37.50 \\
Vocabulary difficulties & 2 & 12.50 \\
Mobile learning & 1 & 6.25 \\
Total & 16 & 100 \\
\hline
\end{tabular}

Table 27. In-depth studies by research field

\begin{tabular}{lcc}
\hline Category & Number & Percentage \\
\hline Technology & 2 & 33.33 \\
Teaching strategies & 2 & 33.33 \\
Grammar difficulties & 2 & 33.33 \\
Mobile learning & 0 & 0.00 \\
Total & 6 & 100 \\
\hline
\end{tabular}

Table 28. In-depth studies by research field

\begin{tabular}{lcc}
\hline Category & Number & Percentage \\
\hline Pronunciation difficulties & 2 & 100 \\
Technology & 0 & 0.00 \\
Teaching strategies & 0 & 0.00 \\
Mobile learning & 0 & 0.00 \\
Total & 2 & 100 \\
\hline
\end{tabular}


studies concentrated on pronunciation difficulties at secondary and university levels. They were undertaken in 2011 and 2015. The findings of those studies showed they had difficu ties in pronouncing certain English consonant sounds. Both findings of the two studies were identical. Female students did not participate in those studies which show a need for investigating their pronunciation problems at all education level.

In concluding, there is a lack of pronunciation studies during the past ten years. Surprisingly, teaching strategies were not experimented at all to solve students' pronunciation problems which is a research gap in this area. Furthermore, using technology and mobile learning was also neglected although technology is vital in teaching pronunciation due the fact that most teachers of English language in Saudi Arabia are non-native speakers of English language which requires applying various kinds of technologies to enhance students' pronunciation.

\section{CONCLUSION AND IMPLICATIONS}

The current emphasis on the significance of English language skills has had a significant impact on educational systems worldwide (Wilson \& Poulter, 2015). As mentioned earlier, Saudi EFL students had serious problems in learning English language due to their lack of effective language skills. Thus, there was a need to conduct a thorough analysis of the previous research on teaching/learning language skills in Saudi Arabia to understand the development of language research during the past ten years. Therefore, this systematic review study sought to examine the trends in teaching/ learning language skills in Saudi Arabia by systematically analyzing the previous studies on language skills which were published within the past ten years and identify the research areas to be bridged in the future.

The search strategy yielded 221 studies for inclusion in the systematic keyword map, and 95 studies for in-depth review. The findings of the systematic review revealed that $(93.67 \%)$ of those studies were published in English language and $(73.30 \%)$ of them were published in foreign peer-reviewed journals. Most of those studies (66.97\%) were undertaken by only one author which reflected the absence of cooperation among researchers in this field. The most frequently used research methodology was the quantitative approach $(81.45 \%)$ which indicates the need for using qualitative and mixed method approaches to gain insight findings in the coming research. Moreover, students sampling presented $(80.09 \%)$ in those studies, and only $(24.43 \%)$ of them were female which requires conducting more studies on Saudi EFL female students. Surprisingly, (73.30\%) of the conducted studies were at university level indicating a limit interest of school-level research. In addition, (68.52\%) of those studies focused on writing, reading skills and achievement indicating the necessity to give more attention to speaking, listening, pronunciation, vocabulary and grammar research at all education sectors in the future. The in-depth review also indicated an obvious focus on reading and writing skills research $(57.14 \%)$, while only $(14.29 \%)$ devoted to grammar, listening and pronunciation. In addition, (67.26\%) of those studies were undertaken at university level which calls for conducting more studies at the school level.

For an in-depth review, writing skill research focused mainly on writing problems at university level neglecting the importance of other education levels. Conversely, no studies were conducted to solve those problems empirically which represent a research gap that should be bridged. In addition, technology use in writing research was only at university level which opens a path for more investigations at all school levels using different kinds of contemporary technologies and mobile learning applications. Regarding reading skill research, most of the participants were university level students. So, more interest is supposed to be devoted to lower level students and to poor reader students who suffered from serious reading difficulties. Reading teaching strategies were not sufficient to solve the severe problems of students since they were rare, and concentrated at one education level or two at most. Moreover, technology and mobile learning were not investigated properly in teaching reading skills since most of the interventions were undertaken to male students or repeated using the same technology at the same education level. On the other hand, listening and speaking skills research were rare and investigated limited levels of education. Listening and speaking problems were not explored well since most of the studies were conducted in higher education. Besides, these two skills can be improved by using an unlimited number of emerging technologies and applications. In fact, rare studies were conducted in this field pointing to a need for more research in this area. In addition, vocabulary research was also limited and had insufficient investigations on students vocabulary learning problems and teaching strategies. Moreover, grammar research was also limited to few studies which were not enough to improve students' grammatical skills. Lastly, pronunciation research was almost neglected. Only two studies were identified, and their findings were identical and proved that Saudi EFL students had serious problems in pronunciation. In fact, no studies investigated any strategies or solutions to overcome those problems at any education level.

As any systematic review study, this review has two main limitations. Firstly, the time limit of the review was only ten years which is almost too short since English language in Saudi Arabia has been taught since 1958. Secondly, there is a level of subjectivity in including the reviewed studies due to the large number of the scanned studies. There was an attempt to reduce this subjectivity in having two independent reviewers and in applying strict criteria for inclusion and exclusion.

The findings of this review suggest that there are some research areas to be explored further in the future. These areas include exploring more research on language skills of Saudi EFL students at the lower levels of education especially on listening, speaking, pronunciation, vocabulary and grammar, andconducting additional language skills research on Saudi EFL female students since gender has an impact on students' English language learning. Besides, struggling readers and writers should be given more research interests to develop their reading and writing proficiencies. Moreover, there is an important scope for research that carries out in- 
terventions aimed at using technologies and mobile learning applications. Since male and female students in Saudi Arabia study separately, cooperation between researchers from both sides in carrying out the same studies on male and female students are fruitful areas for future investigations and comparisons between the two genders.

\section{REFERENCES}

Ababneh, I. (2017). Analysis of Written English: The Case of Female University Students in Saudi Arabia. International Journal of Social Science Studies, 5(4), 1-5.

AbdulFattah, S. (2015). The Effectiveness of Using WhatsApp Messenger as One of Mobile Learning Techniques to Develop Students' Writing Skills. Journal of Education and Practice, 6(32), 115-127.

Ahmad, J. (2011). Pronunciation Problems among Saudi Learners: A Case Study at the Preparatory Year Program, Najran University Saudi Arabia. Language in India, 11(7), 22-36.

Ahmed, F. (2016). An Investigation of Writing Errors of Saudi EFL University Students. International Journal of Social Science and Humanities Research, 4(2), 189-211.

AlAbik, W. (2014). Assessment of Reading Comprehension of Saudi Students Majoring in English at Qassim University, Saudi Arabia. Studies in Literature and Language, 9(1), 155-162.

Alamin, A. (2012). Syntactical and Punctuation Errors: An Analysis of Technical Writing of University Students Science College, Taif University, KSA. English Language Teaching, 5(5), 2-8.

Alamin, A. \& Ahmed, S. (2012). Syntactical and Punctuation Errors: An Analysis of Technical Writing of University Students Science College, Taif University, KSA. English Language Teaching, 5(5), 2-8.

AlAsmari, A. (2015). A Comparative Determination of Barriers of Oral English Learning Faced by Preparatory Year Students. European Scientific Journal, 11(35), 58-81.

Albalawi, F. (2016). Analytical Study of the Most Common Spelling Errors Among Saudi Female Learners of English: Causes and Remedies. Asian Journal of Educational Research, 4(3), 48-62.

Alenazi, M. (2013). Listening Comprehension skill difficu ties as perceived by $1^{\text {st }}$ YearEFL Female Students at Arar College of Education. Journal of Arabic Studies in Education \& Psychology, 41(1), 1-48.

Alhaisoni, E., Al-Zuoud, K. \& Gaudel, D. (2015). Analysis of Spelling Errors of Saudi Beginner Learners of English Enrolled in an Intensive English Language Program. English Language Teaching, 8(3), 185-192.

Al-Hammadi, F. (2011). The Effectiveness of Using a Multi-media Software in Developing Some Listening Skills Among Saudi Secondary School Students. Damascus University Journal, 27 (3+4), 43-86.

Alharbi, A. (2014). The effectiveness of interactive software in acquiring English language reading and speaking skills for sixth grade students. Journal of Faculty of Education in Tanta, 4(1), 465-483.
Al-Hassaani, A. (2016). A Case Study of Question Formations of the Saudi EFL Learners at Bisha University. English Language Teaching, 9(5), 54-64.

Alhawsawi, S. (2013). Investigating student experiences of learning English as a foreign language in a preparatory programme in a Saudi university (Unpublished doctoral dissertation). University of Sussex, Brighton, UK.

AlJiffri, I. (2009). The Effect of Integrating the Task-Based Learning With Computer Assisted Instruction on the Speaking Performance of EFL Learners. Journal of College of Education in Alazhar, 139(3), 423-441.

Al-Johani, H. (2009). Finding a way forward the impact of teachers strategies, beliefs and knowledge on teaching English as a foreign language in Saudi Arabia (Unpublished doctoral dissertation). University of Strathclyde, Glasgow, Scotland, UK.

Aljumah, F. (2011). Developing Saudi EFL Students' Oral Skills: An Integrative Approach. English Language Teaching, 4(3), 84-89.

Al-Khairy, M. (2013a). English as a foreign language learning demotivational factors as perceived by Saudi undergraduates. European Scientific Journal, 9(32), 365-382.

Al-Khairy, M. (2013b). Saudi English-Major Undergraduates' Academic Writing Problems: A Taif University Perspective. English Language Teaching, 6(6), 1-12.

Alkubaidi, M. (2014). The Relationship between Saudi English Major University Students' Writing Performance and Their Learning Style and Strategy Use. English Language Teaching, 7(4), 83-95.

Almubark, A. (2016). Exploring the Problems Faced by the Teachers in Developing English Writing Shills for the Students in Saudi Arabia. International Journal of English Language Teaching, 4(10), 10-23.

Al-Nasser, H. (2015). Problems of English Language Acquisition in Saudi Arabia: An Exploratory-cum-remedial Study. Theory and Practice in Language Studies, 5(8), 1612-1619.

Al-Qahtani, A. (2010). The effectiveness of metacognitive strategies on secondary stage students' achievement and attitudes towards English language (MA thesis). Taif University, Saudi Arabia.

Al-Qahtani, A. (2016). Why Do Saudi EFL Readers Exhibit Poor Reading Abilities?. English Language and Literature Studies, 6(1), 1-15.

Alrabai, F. (2014). A Model of Foreign Language Anxiety in the Saudi EFL Context. English Language Teaching, 7(7), 82-101.

Alrabai, F. (2016). Factors Underlying Low Achievement of Saudi EFL Learners. International Journal of English Linguistics, 6(3), 21-37.

Alrashidi, O. \& Phan, H. (2015). Education Context and English Teaching and Learning in the Kingdom of Saudi Arabia: An Overview. English Language Teaching, 8(5), 33-44.

Al-Roomy, M. (2013). An action research study of collaborative strategic reading in English with Saudi medical students (PhD thesis). University of Sussex, UK.

Alseweed, M. (2009). Attitudes of Saudi Secondary School Level Students Towards Learning of English as a For- 
eign Language. Journal of Arabic and Human, Qassim University, 2(1), 9-22.

Alshahrani, A. (2016). Communicating Authentically: Enhancing EFL Students' Spoken English via Videoconferencing. CALL-EJ, 17(2), 1-17.

Althobaiti, N. (2014). Error Correction in EFL Writing: The Case of Saudi Arabia, Taif University. Journal of Modern Education Review, 4(12), 1038-1053.

Baka, F. (2013). Writing, an Old-New Problem for Arab Learners in King Faisal University English Major Program. Scientific Journal of King Faisal University (Basic and Applied Sciences), 14(1), 329-347.

Bettany-Saltikov, J. (2012). How to Do a Systematic Literature Review in Nursing: A Step-By-Step Guide. Berkshire: Open University Press.'

Carfax Educational Projects (2016). English Language Market Reports: Gulf States - Saudi Arabia: A report prepared for the UK's English language sector. UK: British Council.

Deng, Q. \& Trainin, G. (2015). Learning Vocabulary with Apps: From Theory to Practice. The Nebraska Educator: A Students-Led Journal, 29, 49-69.

EF English Proficiency Index (EPI). (2017). Available at: http://www.ef.com/sa/epi/[Accessed 13 April 2017].

Elyas, T., \& Picard, M. (2010). Saudi Arabian educational history: Impacts on English language teaching. Education, Business and Society: Contemporary Middle Eastern Issues, 3(2), 136-145.

ETS. (2016). Test and score data summaries. Available at: https://www.ets.org/toefl_itp/research/[Accessed 14April2017].

Faruk, S. (2013). English language teaching in Saudi Arabia: A world system perspective. Scientific Bulletin of the Politehnica University of Timisoara. Transactions on Modern Languages, 12(1-2), 73-80.

Freihat, N. \& AlZamil, A. (2014). The Effect of Integrating MOOC'S on Saudi Female Students' Listening Achievement. European Scientific Journal, 10(34), 127-142.

Grami, G. (2012). Online Collaborative Writing for ESL Learners Using Blogs and Feedback Checklists. English Language Teaching, 5(10), 43-48.

Grami, G. \& Alkazemi, B. (2016). Improving ESL writing using an online formulaic sequence word-combination checker. Journal of Computer Assisted Learning, 32, 95-104.

Habbash, M. \& Idapalapati, S. (2016). Distinctiveness of Saudi Arabian EFL Learners. Advances in Language and Literary Studies, 7(2), 113-120.

Hago, O. \& Khan, W. (2015). The Pronunciation Problems Faced by Saudi EFL Learners at Secondary Schools. Education and Linguistics Research, 1(2), 85-99.

Hall, G. (Ed.). (2016). The Routledge Handbook of English Language Teaching. New York: Routledge.

Hamad, M. (2013). Factors Negatively Affect Speaking Skills at Saudi Colleges for Girls in the South. English Language Teaching, 6(12), 87-97.

Hameed, P. (2016). A Study of the Spelling Errors committed by Students of English in Saudi Arabia: Exploration and Remedial Measures. Advances in Language and Literary Studies, 7(1), 203-207.

Hamouda, A. (2013a). An Investigation of Listening Comprehension Problems Encountered by Saudi Students in the EL Listening Classroom. International Journal of Academic Research in Progressive Education and Development, 2(2), 113-155.

Hamouda, A. (2013b). An Exploration of Causes of Saudi Students' Reluctance to Participate in the English Language Classroom. International Journal of English Language Education, 1(1), 17-34.

IELTS. (2016). Test taker performance for 2015. Available at: https://www.ielts.org/teaching-and-research/test-taker-performance [Accessed 14 April 2017].

Javid, C. (2013). An Investigation of Effectiveness of Simulation in Developing Oral Skills: A Case Study. European Scientific Journal, 9(32), 254-270.

Javid, C., Farooq, U. \& Umer, M. (2013). An Investigation of Saudi EFL learners' Writing Problems: A Case Study along Gender-lines. Kashmir Journal of Language Research, 16(1), 179-203.

Javid, C. \& Umer, M. (2014). Saudi EFL Learners "Writing Problems: A Move Towards Solution. Proceeding of the Global Summit on Education GSE, 4-5 March, Kuala Lumpur, Malaysia.

Lau, J. (2007).Evidence-Based Medicine and Meta-Analysis: Getting More Out of the Literature. R. Greenes (Ed.), Clinical Decision Support: The Road Ahead (pp. 249-264). Burlington: Elsevier, Inc.

Littell, J., Corcoran, J. \& Pillai, V. (2008). Systematic Reviews and Meta-Analysis. New York: Oxford University Press, Inc.

Littlejohn, A. (2013). The Social Location of Language Teaching: From Zeitgeist to Imperative. In A. Ahmed, M. Hanzala \&F. Saleem (Eds.), ELT in a Changing World: Innovative Approaches to New Challenges (pp. 3-16). Cambridge: Cambridge Scholars Publishing.

Mahmoud, S. (2013). The Effect of Using English SMS on KAU Foundation Year Students' Speaking and Writing Performance. American International Journal of Social Science, 2(2), 13-22.

Ministry of Education, KSA. (2017). Ministry of Education: Statistical Report. Available at: https://www.moe. gov.sa/ar/Pages/StatisticalInformation.aspx [Accessed 12 April 2017].

Ministry of Finance. (2017). Annual Budget Report. Riyadh, Saudi Arabia.

Murrey, N, \& Beglar, D. (2009). Inside track: writing dissertations and theses. Dorset: Henry Ling Ltd.

Naikoo, I., Ganai, P. \& Tawhari, S. (2016). Errors in English Paragraph Writing Made by Jazan University Students: A Linguistic Analysis. International Journal of Social Science and Humanities Research, 4(1), 473-479.

Nezami, S. (2012). A Critical Study of Comprehension Strategies and General Problems in Reading Skill Faced by Arab EFL Learners with Special Reference to Najran University in Saudi Arabia. International Journal of Social Sciences and Education, 2(3), 306-316. 
Rahman, M. \& Alhaisoni, E. (2013). Teaching English in Saudi Arabia: Prospects and Challenges. Academic Research International, 4(1), 112-118.

Raja, Z. \& Zahid, R. (2013). Enhancing Writing Skills: An Analytical Study of Obstacles in Writing at B. A. Level in Najran University, KSA. Studies in Literature and Language, 7(2), 1-7.

Rajab, H. (2013). Developing speaking and writing skills of L1 Arabic EFL learners through teaching of IPA phonetic codes. Theory and Practice in Language Studies, 3(4), 653-659.

Sawalmeh, M. (2013). Error Analysis of Written English Essays: The case of Students of the Preparatory Year Program in Saudi Arabia. English for Specific Purposes World, 40(14), 1-16.

Seargeant, P. (2016). World Englishes and English as a Lingua Franca: a changing context for ELT. In G. Hall (Ed.), The Routledge Handbook of English Language Teaching (pp.13-25). New York: Routledge.
Sharifian, F. (Ed.). (2009). English as an International Language: Perspectives and Pedagogical Issues. Bristol: Multilingual Matters.

Siddiqui, M. (2015). Evaluating Capitalization Errors in Saudi Female students' EFL writing at Bisha University. Arab World English Journal (AWEJ), 6(1), 232-250.

Wilson, R. \& Poulter, M. (Eds.). (2015). Assessing Language Teachers' Professional Skills and Knowledge. Cambridge: Cambridge University Press.

Younes, Z. \& Albalawi, F. (2015). Exploring the Most Common Types of Writing Problems Among English Language and Translation Major Sophomore Female Students at Tabuk University. Asian Journal of Basic and Applied Sciences, 3(2), 7-26.

Younes, Z. \& Albalawi, F. (2016). Investigating the Factors Leading to Speaking Difficulties: Both Perspectives of EFL Saudi Learners and Their Teachers. Arab World English Journal (AWEJ), 7(2), 268-287.

Author Query???

AQ1: KIndly cite tables $10-12,14,16,18,19$ in text part 